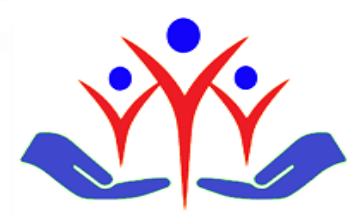

Family Practice and Palliative Care

doi https://doi.org/10.22391/fppc.787707

Research Article

\title{
Causes of hypertransaminasemia in children, single-center experience
}

Çocuklarda hipertransaminazeminin nedenleri, tek merkez deneyimi

\author{
(D) Meryem Keceli Basaran ${ }^{\mathbf{a}}$ (iD Tuba Cicek ${ }^{\mathbf{b}}$

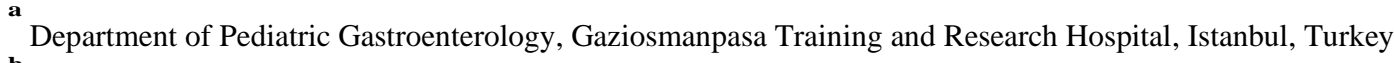 \\ Department of Pediatrics, Gaziosmanpasa Training and Research Hospital, Istanbul, Turkey
}

\begin{abstract}
Introduction: When transaminase levels (Alanine aminotransferase: ALT, Aspartate aminotransferase: AST) are high, a causal investigation is necessary. Although the etiology and frequency of hypertransaminasemia have been examined at length in the adult population, research addressing pediatric patients is far from being sufficient in number. The objective of this study is to investigate the causes the hypertransaminasemia. We think that knowing the most common causes of hypertransaminasemia in children will help primary care physicians with diagnosis and follow-up. Methods: The patients who were admitted to the pediatric gastroenterology policlinic between 2018- 2019 with ALT> 45 IU /L and/or AST> 50 IU /L levels were the subjects of this study. They all displayed elevated liver function test (LFT) results due to various conditions including liverrelated ones and others. The medical records of the patients, who were between 6 months and 18 years of age, were analyzed.

Results: Of 237 patients included in the study, $127(54 \%)$ were male and $110(46 \%)$ were female. The mean age of the patients was $75.40 \pm 60.50$ months. 5.06\% of the patients had fever, $11.39 \%$ had hepatomegaly, $7.59 \%$ suffered from loss of appetite and $7.59 \%$ had abdominal pain. The obesity rate was at $9.70 \%$ while splenomegaly was detected in $2.11 \%$ of the patients. Elevation of liver enzymes was found to be related with idiopathic causes $35 \%(\mathrm{n}=83)$, viral infections $21 \%(\mathrm{n}=50)$, hepatosteatosis $15 \%(\mathrm{n}=38)$, and medication $8.80 \%(\mathrm{n}=21)$.

Conclusion: Hypertransaminasemia may be an outcome of primary diseases of the liver and it may also be aggravated due to secondary effects. NAFLD (non-alcoholic fatty liver disease, viral infections, and medication continue to be among the most common causes. NAFLD constitutes an important cause of hypertransaminemia in children.

Keywords: child, liver function tests, fatty liver
\end{abstract}

$\ddot{O} \mathbf{z}$

Giriş: Çocuklarda transaminaz düzeyleri (Alanin amino transferaz: ALT, Aspartat aminotransferaz: AST) yüksek olduğunda etyolojiye yönelik araştırmalar yapılmalıdır. Yetişkin popülasyonda yapılan çalışmalarda hipertransaminazeminin etiyolojisi ve sıklığı ayrıntılı olarak incelenmiş olsa da, pediatrik hastaları ele alan araştırma sayısı yeterli değildir. Bu çalışmanın amacı hipertransaminazeminin nedenlerini araştırmaktır. Çocuklarda hipertransaminazeminin en yaygın nedenlerini bilmenin, birinci basamak hekimlerine tanı ve takipte yardımcı olacağını düşünüyoruz. Yöntem: 2018-2019 yılları arasında ALT> 45 IU / L ve / veya AST> 50 IU / L düzeyleri ile pediyatrik gastroenteroloji polikliniğine başvuran hastalar incelendi. 6 ay ile 18 yaş arasındaki karaciğer fonksiyon testleri yüksek olan hastaların tıbbi kayıtları analiz edildi.

Bulgular: Çalışmaya dahil edilen 237 hastanın 127'si (\%54) erkek, 110'u (\%46) kadındı. Hastaların ortalama yaş1 75,40 $\pm 60,50$ ay idi. Hastaları\% \%5,06'sında ateş, \%11,39'unda hepatomegali, \%7,59'unda iştah kaybı ve \%7,59'unda karın ağrısı vardı. Obezite oranı \%9,70 iken, hastaların \%2,11'inde splenomegali saptand1. Karaciğer enzimlerinin yükselmesi idiyopatik nedenler \%35 $(\mathrm{n}=83)$, viral enfeksiyonlar \%21 $(\mathrm{n}=$ 50), hepatosteatoz $\% 15(\mathrm{n}=38)$ ve ilaç $\% 8,80(\mathrm{n}=21)$ ile ilişkili bulunmuştur.

Sonuç: Hipertransaminazemi karaciğerin primer hastalıklarının bir sonucu olabilir ve sekonder etmenler nedeniyle de şiddetlenebilir. NAFLD (non-alkolik yağlı karaciğer hastalığı), viral enfeksiyonlar ve ilaç kullanımı en yaygın nedenler arasında olmaya devam etmektedir. NAFLD, çocuklarda hipertransaminazeminin önemli bir nedenini oluşturmaktadır.

Anahtar Kelimeler: çocuk, karaciğer fonksiyon testleri, yağlı karaciğer

\begin{tabular}{|c|c|c|c|c|}
\hline Received & Accepted & Published Online & Corresponding Author & E-mail \\
\hline August 29, 2020 & March 19, 2021 & April 3, 2021 & Meryem Keceli Basaran, M.D. & meryem.keceli07@yahoo.com \\
\hline Correspondence & \multicolumn{2}{|l|}{$\begin{array}{l}\text { Dr. Meryem Keçeli Başaran. Gaziosmanpaşa Training and Research Hospital, Karayollari disstrict, } \\
\text { Osmanbey Avenue, Street 621, Gaziosmanpaşa / İstanbul, Turkey }\end{array}$} \\
\hline
\end{tabular}




\section{Introduction}

Liver function tests are widely used for diagnosis, monitoring, and prognosis of liver disease. Serum aminotransferases are an easily measurable, low-cost screening tool for detecting asymptomatic liver disease. Both alanine aminotransferase (ALT) and aspartate aminotransferase (AST) generally level within the normal range in healthy individuals [1-3]. When transaminase values (ALT, AST) are high, a causal investigation should is necessary. Although transaminase elevation generally suggests liver illnesses, it may also rise due to systemic or other organ diseases. For instance, blood diseases and processes leading to hemolysis are among the most typical conditions [4-6]. In toxic, metabolic, inflammatory and traumatic conditions, the liver may be affected secondarily. Elevated liver enzyme level, in this case, may not be the cause of the disease; but rather its result. It has been shown in various studies that the frequency and the causes of liver enzyme elevation vary from region to region and according to the socio-economic development of the country. While infections in underdeveloped nations are an important cause of liver enzyme elevation, another reason for liver enzyme elevation is medication. Liver enzyme elevation (DILI) associated with drugs is a rare adverse drug reaction. It can cause jaundice, liver failure, and even death. Antimicrobials, herbal and dietary supplements are among the most common causes. DILI is an exclusionary diagnosis and therefore, a careful anamnesis and a comprehensive study of etiologies are necessary for timely diagnosis. NAFLD due to obesity has been indicated as the most common cause in developed countries [7,8]. Although the etiology and frequency of hypertransaminasemia have been studied in detail in the adult populations, there are not enough studies addressing pediatric patients [9]. It has been shown that the rate of hypertransaminasemia in the pediatric patient segment ranges between 3.50-12.40\% [10]. In this study, we have investigated the causes of liver enzyme elevation as well as the importance of laboratory tests in its etiology.

\section{Methods}

This cross-sectional study has been undertaken by a retrospective examination of the patient files from the hospital database. The medical records of the patients between 6 months and 18 years of age who were admitted to the Pediatric Gastroenterology clinic between 2018 and 2019 with ALT> $45 \mathrm{IU} / \mathrm{L}$ and/or AST> $50 \mathrm{IU} / \mathrm{L}$ and elevated liver function tests due to the liver and non-liver related causes were put into analysis. ALT and AST activities of all patients were measured with the enzymatic method (Roche, Hitachi 747, Brahms, Germany). AST> 50 IU / L and ALT> $45 \mathrm{IU} / \mathrm{L}$ were evaluated as high in comparison with the literature [11]. Patients whose test results displayed elevated liver enzyme levels at least twice in the last 3 months were included in the study. Patients with an underlying chronic disease, patients with epilepsy and cerebral palsy, patients with immunodeficiency (liver function tests may deteriorate because of frequent infection) were excluded. Autoimmune hepatitis (AIH) was examined based on the criteria set by the International Autoimmune Hepatitis Group [12]. Abdominal usg was performed on all patients. Hepatomegaly and splenomegaly, abdominal usg was determined. The body mass index used for obesity was examined. If $\mathrm{BMI}>30 \mathrm{~kg} / \mathrm{m}^{2}, \mathrm{patients}$ were considered obese [13]. Patients with medication-dependent liver enzyme elevation were also included in the study. The diagnosis of suspected drug-induced liver injury (DILI) is following the American College of Gastroenterology Clinical Guideline [14]. The diagnosis of suspected druginduced liver injury (DILI) (hepatocellular type injury) is defined by ALT> 2 ULN (upper limits of normal) in the patients. The diagnosis of DILI was made according to the history of drug use and pathological findings, after excluding the reasons that increased other liver function tests. The diagnosis of NAFLD was based on the presence of hepatic steatosis in the absence of underlying metabolic and toxic causes (drugs, alcohol, etc.). Moreover, NAFLD diagnosis was made according to US findings and biopsy results after excluding autoimmune hepatitis, Wilson's disease, viral hepatitis, and metabolic diseases. The ratio between AST and ALT levels (De Ritis ratio) was instrumental while making a differential diagnosis. (Table-1) [15].

Table 1. De Ritis ratio (AST / ALT) and diseases considered in etiology

\begin{tabular}{lll}
\hline \multicolumn{1}{c}{ AST $/$ ALT $\leq \mathbf{1}$} & \multicolumn{1}{c}{ AST/ALT $>\mathbf{1}$} & \multicolumn{1}{c}{ AST/ALT $>\mathbf{4}$} \\
\hline Acute liver diseases & Cirrhosis & Fulminant liver diseases \\
NAFLD & Infiltrative causes & Wilson's disease \\
Cholestatic hepatitis & Hematological diseases & \\
Viral hepatitis & Muscle diseases & \\
& Metabolic diseases & \\
\hline
\end{tabular}

\section{Ethical Approval}

The Ethics Committee for Clinical Research of the local hospital (Taksim training and research hospital) approved the study (date: 27.03 .2019 and no:42).

\section{Statistical analysis}

In summarizing the data obtained from the study, descriptive statistics were provided in tabular form as mean \pm standard deviation or width between median to quartile for continuous variables. Categorical variables were summarized as numbers and percentages. The normality test of numerical variables was checked by the Kolmogorov Smirnov test. Mann-Whitney U test was used for the comparison of two independent groups with non-normal distributions. Pearson Chi-Square test was used in 2x2 tables and Fisher's Exact Test was used in RxC tables.

Jamovi project computer software (Version 0.9.6.9, 2019-retrieved from https://www.jamovi.org) was used in the statistical tests and the significance level was determined at 0.05 (p-value). 


\section{Results}

The patients were included in the study as shown in Figure-1.

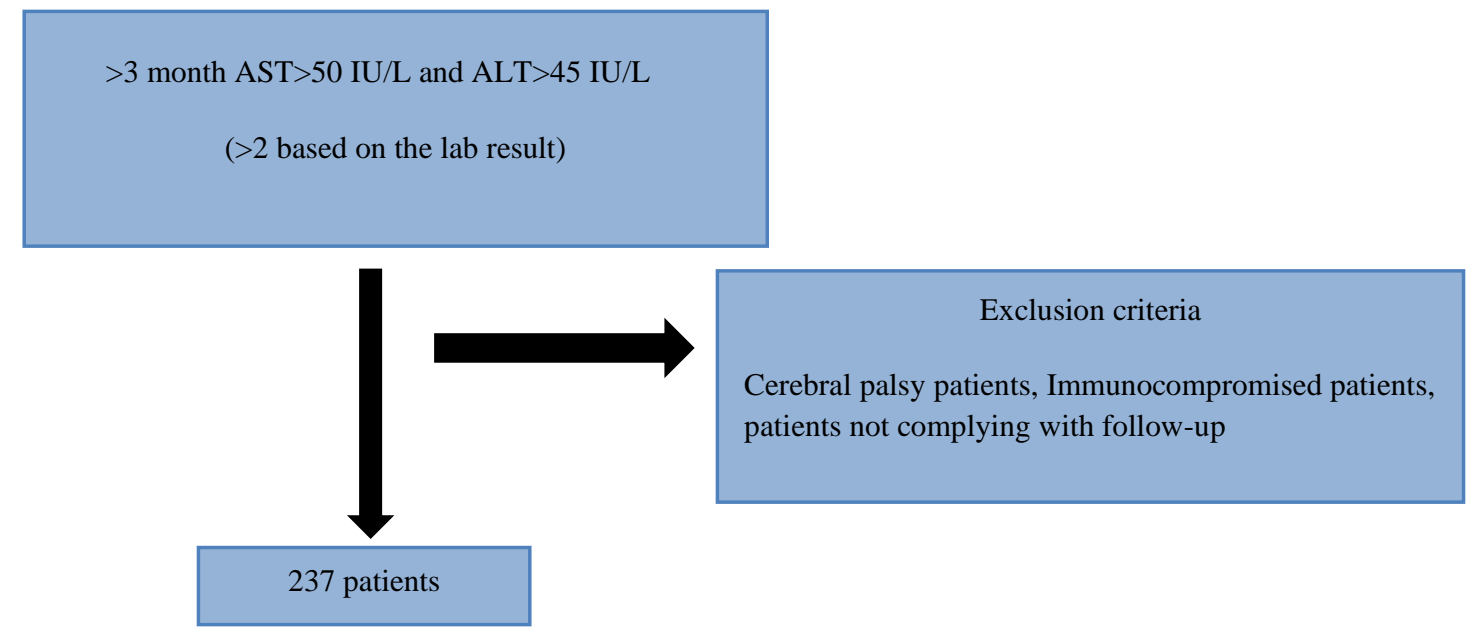

Figure 1: Inclusion and exclusion flow chart of the patients.

The study population consisted of 237 subjects. $54 \%$ of the patients were male and $46 \%$ female (Table 2). The mean age was $75.48 \pm 60.52$ months. $5.06 \%$ of the patients had fever, $11.39 \%$ had hepatomegaly, $7.59 \%$ had anorexia, $7.59 \%$ had abdominal pain, $9.70 \%$ were obese and in $2.11 \%$ of the patients, splenomegaly was detected. Table 2 displays the mean and median values of liver enzymes as well as other clinical values of the patients in this study.

Table 2. Demographic and clinical findings of patients

\begin{tabular}{|c|c|}
\hline $\mathbf{n}$ & 237 \\
\hline Age (months) & $75.48 \pm 60.52$ \\
\hline \multicolumn{2}{|l|}{ Gender $(\%)$} \\
\hline Male & $128(54)$ \\
\hline Female & $109(46)$ \\
\hline Number of Admissions & $3.21 \pm 1.79$ \\
\hline Follow-up Duration (month) & $7.48 \pm 3.14$ \\
\hline Fever, yes (\%) & $12(5.06)$ \\
\hline Hepatomegaly, yes (\%) & $27(11.39)$ \\
\hline Anorexia, yes (\%) & $18(7.59)$ \\
\hline Nausea, yes (\%) & $18(7.59)$ \\
\hline Abdominal pain, yes (\%) & $6(2.53)$ \\
\hline Obesity, yes (\%) & $23(9.70)$ \\
\hline Splenomegaly, yes (\%) & $5(2.11)$ \\
\hline ALT, $U / L$ & $113[78-194]$ \\
\hline AST, $U / L$ & $89[64-165]$ \\
\hline GGT, $U / L$ & $34[16-62]$ \\
\hline T. Bilirubin, $m g / d l$ & $0.57[0.37-0.90]$ \\
\hline D. Bilirubin, $m g / d l$ & $0.30[0.13-0.60]$ \\
\hline ALP, $U / L$ & $255[185-304]$ \\
\hline Albumin, $m g / d l$ & $4.10[4-4.4]$ \\
\hline Hemoglobin, $g / l$ & $12.20[11.20-13]$ \\
\hline
\end{tabular}

Descriptive statistics are provided as, median [interquartile width] and number $(\%)$.

ALT: Alanine aminotransferase, AST: Aspartate aminotransferase, GGT: Gamma-Glutamyl Transferase,

T. Bilirubin: Total bilirubin, D. Bilirubin: Direct bilirubin, ALP: Alkaline phosphatase 
Table 3. Diagnoses of patients included in the study

\begin{tabular}{|l|l|}
\hline \multicolumn{1}{|c|}{$\mathrm{n}(\%)$} \\
\hline Idiopathic & $83(35.02)$ \\
\hline Viral & $50(21.10)$ \\
\hline Hepatic steatosis & $38(15.19)$ \\
\hline Medicine-related & $21(8.86)$ \\
\hline Hepatitis A, B & $6(2.53)$ \\
\hline Muscle disease & $8(2.53)$ \\
\hline Autoimmune hepatitis & $5(2.11)$ \\
\hline Posttraumatic & $5(2.11)$ \\
\hline EBV & $4(1.68)$ \\
\hline Celiac & $3(1.26)$ \\
\hline PFIC 3 & $3(1.26)$ \\
\hline PFIC 1 & $3(1.26)$ \\
\hline Metabolic disease & $2(0.84)$ \\
\hline Neonatal hepatitis & $2(0.84)$ \\
\hline Alagille & $1(0.42)$ \\
\hline Wilson & $1(0.42)$ \\
\hline
\end{tabular}

Descriptive statistics provided in number $(\%)$.

EBV: Epstein-Barr virus,

PFIC 3: progressive familial intrahepatic cholestasis type3,

PFIC1: progressive familial intrahepatic cholestasis type1

The most common causes of patients presenting with liver enzyme elevation were idiopathic causes, viral infections, and hepatic steatosis (Table 3). Patients with Hepatitis A, B, and EBV (Epstein Barr Virus) infections were also included among 50 pediatric patients with hypertransaminasemia due to viral infection. In other words, a viral infection agent was not detected in 40 patients. The clinical findings suggested the presence of viral infection.

In Table 4, the mean ALT and AST values based on etiology are provided. Accordingly, the mean ALT and AST values were higher in the case of autoimmune hepatitis and Wilson disease.

Table 4. ALT and AST values based on diagnosis

\begin{tabular}{|l|c|c|c|}
\hline & $\mathbf{n}(\boldsymbol{\%})$ & ALT (U/L) [range] & AST (U/L) [range] \\
\hline Idiopathic & 35 & $89[71-121]$ & $78[61-128]$ \\
\hline Viral & 21 & $132.50[89-190]$ & $92[69-201]$ \\
\hline Hepatosteatosis & 15 & $110.50[75-169]$ & $68[56-115.50]$ \\
\hline Medicine related & 8.8 & $117[59-175]$ & $89[58-146]$ \\
\hline Hepatitis A, B & 2.5 & $112[67-540]$ & $88[70-365]$ \\
\hline Muscle Disease & 2.5 & $328.50[310-440]$ & $247[153-488]$ \\
\hline Autoimmune Hepatitis & 2 & $540[480-709]$ & $397[365-1179]$ \\
\hline Posttraumatic & 2 & $361[361-433]$ & $490[490-630]$ \\
\hline EBV & 1.6 & $215[173.50-271]$ & $174.50[127.50-221]$ \\
\hline Celiac disease & 1.2 & $113[94-113]$ & $63[63-64]$ \\
\hline PFIC 3 & 1.2 & $279[279-342]$ & $161[161-365]$ \\
\hline PFIC 1 & 1.2 & $126[126-234]$ & $50[50-185]$ \\
\hline Metabolic disease & 0.8 & $308[308-308]$ & $165[165-165]$ \\
\hline Neonatal hepatitis & 0.8 & $218[180-256]$ & $168.50[117-220]$ \\
\hline Alagille & 0.4 & $136[136-136]$ & $138[138-138]$ \\
\hline Wilson disease & 0.4 & $685[685-685]$ & $332[332-332]$ \\
\hline
\end{tabular}

Descriptive statistics are provided as median [interquartile width] and number (\%).

EBV: Epstein-Barr virus,

PFIC 3: progressive familial intrahepatic cholestasis type3,

PFIC1: progressive familial intrahepatic cholestasis type1

\section{Discussion}

The findings associated with elevated liver enzyme levels in children may vary. Most often, a diagnosis of liver enzyme elevation can be made by chance without any finding. Moreover, NAFLD and viral infections were identified as the most common causes of liver enzyme elevation. Iorio et al. noted a high level of the idiopathic enzyme for $31.7 \%$ of their patients. [16,17]. A recent study on hospitalized pediatric patients in Turkey investigated the causes and the rate of transaminase elevation. Celtik et al. [18] reported a ratio of idiopathic enzyme elevation as $27.1 \%$ among their patients and added that the liver test results of these patients returned to normal levels within a year. The enzyme levels of the monitored patients returned to normal levels within 6 months in the latter study. In our study, when we examined the complaints of the pediatric gastroenterology clinic; we observed that the most common reasons for admission were related to nausea and reduced appetite. In another study conducted in Turkey, fatigue has been cited as the most frequent complaint (53.40\%). Similarly, the most common physical examination finding was hepatomegaly [19]. Hepatitis A infection is the most common cause of hypertransaminasemia in underdeveloped countries while NAFLD- 
related enzyme elevation is the most typical cause in developed nations. In a study conducted in China, the rate of acute hepatitis A fell from $31 \%$ to $2 \%$ in 6235 patients between 2002 and 2011. Drug-induced liver damage (DILI) has been reported with a rate of less than 5\% [20]. Similarly, drug-related liver enzyme elevation was detected at a rate of $8.8 \%$ in our study. A patient with suspected DILI should be thoroughly examined for other liver diseases, especially viral hepatitis. NAFLD is the most common liver disease in the United States (10\% -46\%) and it should always be suspected. In some patients, DILI and NAFLD can be observed simultaneously. Aminotransferase levels in NAFLD usually rise 2-5 times the upper limit of normal, and alkaline phosphatase values are 2-3 times the upper limit of normal. Results exceeding these values should also suggest the coexistence of different diseases, including DILI. Antinuclear antibody and anti-smooth muscle antibody counts may also be high in approximately $20 \%$ of patients with NAFLD [21]. According to our study, idiopathic causes are the most common, but viral infections and hepatic steatosis are among the other common causes. NAFLD is a significant cause of liver enzyme elevation in developed countries [22]. The diagnosis of NAFLD is usually made following the identification of abnormal serum aminotransferases in obese patients. Serum AST and ALT may rise to 5 times the normal or may increase slightly or not at all. ALT / AST ratio is usually greater than one. The gold standard for diagnosis is a liver biopsy. Purcell et al. reported that $84 \%$ of patients with NAFLD-induced elevated liver enzymes were obese [23]. In our study, NAFLD-induced enzyme elevation was present in 38 patients $(15.1 \%)$. The obesity rate among our patients was $9.7 \%$.

\section{Limitations}

There were several limitations to this study. One of them was the normal and upper limit of ALT and AST values assumed for the Turkish society. Moreover, when the files of some patients were examined, it was noted that there were not enough outpatient controls. Therefore, some of the patients had to be excluded from the study due to diagnostic deficiency while being evaluated for hypertransaminasemia in the follow-up.

\section{Conclusion}

In literature, high enzyme levels are associated with viral infections mostly. As a result, hypertransaminasemia may occur as a result of primary diseases of the liver, but it may also rise due to secondary effects. NAFLD, viral infections, and medication continue to be among the most common causes. Furthermore, a history of systemic diseases, muscle diseases, and trauma should be taken into consideration, as well.

Conflict of interest: None.

\begin{tabular}{|l|l|l|}
\hline \multicolumn{2}{|c|}{ Author Contributions } & \multicolumn{1}{c|}{ Author Initials } \\
\hline SCD & Study Conception and Design & MKB, TC \\
\hline AD & Acquisition of Data & TC \\
\hline AID & Analysis and Interpretation of Data & MKB \\
\hline DM & Drafting of Manuscript & MKB, TC \\
\hline CR & Critical Revision & MKB, TC \\
\hline
\end{tabular}

Financial support: None

\section{References}

1. Schwimmer JB, Dunn W, Norman GJ, Pardee PE, Middleton MS, Kerkar N, et al. SAFETY study: alanine aminotransferase cutoff values are set too high for reliable detection of pediatric chronic liver disease. Gastroenterology 2010; 138(4):1357-64 http://dx.doi.org/10.1053/j.gastro.2009.12.052.

2. Park SH, Park HY, Kang JW, Park J, Shin KJ. Aminotransferase upper reference limits and the prevalence of elevated aminotransferases in the Korean adolescent population. J Pediatr Gastroenterol Nutr 2012;55(6):668-72.

3. Park HK, Hwang JS, Moon JS, Lee JA, Kim DH, Lim JS. Healthy range of serum alanine aminotransferase and its predictive power for cardiovascular risk in children and adolescents. J Pediatr Gastroenterol Nutr 2013;56(6):686-91.

4. Giannini EG, Testa R, Savarino V. Liver enzyme alteration: a guide for clinicians. CMAJ 2005;172(3):367-79. http://dx.doi.org/10.1503/cmaj.1040752.

5. Green RM, Flamm S. AGA technical review on the evaluation of liver chemistry tests. Gastroenterology 2002; 123(4):1367-84. http://dx.doi.org/10.1053/gast.2002.36061.

6. Vajro P, Maddaluno S, Veropalumba C. Persistent hypertansaminasemia in asymptomatic children: a stepwise approach. World J Gastroenterol 2013;19(18):2740-51. http://dx.doi.org/10.3748/wig.v19.i18.2740.

7. Hennes HM, Smith DS, Schneider K, Hegenbarth MA, Duma MA, Jona JZ. Elevated liver transaminase levels in children with blunt abdominal trauma: a predictor of liver injury. Pediatrics 1990; 86(1):87-90.

8. Kleiner DE, Chalasani NP, Lee WM, Fontana RJ, Bonkovsky HL, Watkins PB, et al. Drug-Induced Liver Injury Network (DILIN). Hepatic histological findings in suspected drug-induced liver injury: systematic evaluation and clinical associations. Hepatology 2014; 59(2):661-70. http://dx.doi.org/10.1002/hep.26709.

9. Hyun HJ, Shim JJ, Kim JW, Lee JS, Lee CK, Jang JY, et al. The prevalence of elevated alanine transaminase and its possible causes in the general Korean population. J Clin Gastroenterol 2014; 48(6):534-9. http://dx.doi.org/10.1097/MCG.0b013e3182a474dd3.

10. Fraser A, Longnecker MP, Lawlor DA. Prevalence of elevated alanine aminotransferase among US adolescents and associated factors: NHANES 1999-04. Gastroenterology 2007; 133(6):1814-20. http://dx.doi.org/10.1053/j.gastro.2007.08.077.

11. Hudson OD, Nunez M, Shaibi GQ. Ethnicity and elevated liver transaminases among newly diagnosed children with type 2 diabetes. BMC Pediatr 2012; 12:174. http://dx.doi.org/10.1186/1471-2431-12-174.

12. Alvarez F, Berg PA, Bianchi FB, Bianchi L, Burroughs AK, Cancado EL, et al. International Autoimmune Hepatitis Group Report: review of criteria for diagnosis of autoimmune hepatitis. J Hepatol 1999; 31(5):929-38. http://dx.doi.org/10.1016/S0168-8278(99)80297-9. 
13. Baya Botti A, Pèrez-Cueto FJ, Vasquez Monllor PA, Kolsteren PW. Anthropometry of height, weight, arm, wrist, abdominal circumference and body mass index, for Bolivian adolescents 12 to 18 years Bolivian adolescent percentile values from the MESA study. Nutr Hosp 2009;24:304-11. PMID: 19721903

14. Chalasani NP, Hayashi PH, Bonkovsky HL, Navarro VJ, Lee WM, FACG, et al. ACG Clinical Guideline:the diagnosis and management of idiosyncratic drug-induced liver injury. Am J Gastroenterol. http://dx.doi.org/10.1038/ajg.2014.131.

15. Botros M1, Sikaris KA. The de ritis ratio: The test of time. Clin Biochem Rev, 2013;34:117-30.

16. Iorio R, Sepe A, Giannattasio A, Cirillo F, Vegnente A. Hypertransaminasemia in childhood as a marker of genetic liver disorders. J Gastroenterol 2005; 40(8):820-6. https://doi.org/10.1007/s00535-005-1635-7.

17. Nobili V, Reale A, Alisi A, Morino G, Trenta I, Pisani M, et al. Elevated serum ALT in children presenting to the emergency unit: Relationship with NAFLD. Dig Liver Dis 2009; 41(10):749-52. http://dx.doi.org/10.1016/j.dld.2009.02.048.

18. Çeltik C, Erbaş H, Kurşun OS, Bostancioglu M, Inan M, Oner N, et al. The reasons of elevated serum transaminases in childhood [Article in Turkish]. Turk J Biochem 2008; 33(4):175-81. https://doi.org/10.7197/cmj.vi.593477.

19. Gilbert-Barness E, Barness LA, Farrell PM . Clinical use of pediatric diagnostic tests, 3rd ed. Philadelphia: Lippincott, Williams \& Wilkins; 2003.

20. Shen G, Zhang L, Zhang YL, Hu LP, Li MH, Lu Y, et al. Study on the etiology of acute hepatitis hospitalized patients in Beijing Ditan Hospital from 2002 to 2011. Zhonghua Shi Yan He Lin Chuang Bing Du Xue Za Zhi. 2013 Aug;27(4):266-9. Chinese. PMID: 24579471.

21. Leise MD, Poterucha JJ, Talwalkar JA. Drug-induced liver injury. Mayo Clin Proc. 2014 Jan;89(1):95-106. doi: 10.1016/j.mayocp.2013.09.016. PMID: 24388027.

22. Serdaroglu F, Koca T, Dereci S, Akcam M. The etiology of hypertransaminasemia in Turkish children. Bosn J Basic Med Sci. 2016;16(2):1516. http://dx.doi.org/10.17305/bjbms.2016.982.

23. Purcell M, Flores YN, Zhang ZF, Denova-Gutiérrez E, Salmeron J. Prevalence and predictors of alanine aminotransferase elevation among normal weight, overweight and obese youth in Mexico. J Dig Dis 2013; 14(9):491-9. http://dx.doi.org/10.1111/1751-2980.12072. 